\title{
Thematic Module Based on Groundwater Quality to Enhance Creative Thinking Abilities and Student Perceptions
}

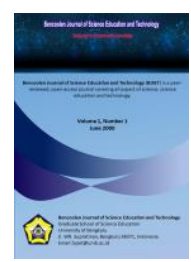

\author{
Yarni Sri Yanti*, Afrizal Mayub, Nirwana \\ Physics Education Department, University of Bengkulu, Indonesia \\ *Email: yarnisriyanti@gmail.com
}

DOI: $\underline{\text { https://doi.org/10.33369/bjset.v1i1.11183 }}$

\begin{abstract}
This study aimed to (1) Describe groundwater quality in terms of physical and chemical parameters; (2) Describe the improvement of the ability to think creatively using thematic modules on the impacts of pollution on life; and (3) Describe the increase in students' perceptions of the importance of caring for the environment using the thematic modules on the material about impacts of pollution on life. The type of research used is the Research and Development (R\&D) development model of ADDIE (Analysis, Design, Development, Implementation and Evaluation). The analysis phase was carried out on ground water quality using 7 parameters, namely temperature, $\mathrm{pH}$, dissolved oxygen levels, salinity, TDS, turbidity and electrical conductivity. The results of the analysis were packaged in a thematic module on the impact of pollution on life for class VII SMP / MTs as an effort to improve students' creative thinking abilities and perceptions of caring for the environment. The sample of the study was SMPN 18 Bengkulu Tengah students, for a limited scale there were 10 students of class VIII, while the broad scale were 21 students of class VII. Data analysis was performed using the $\mathrm{N}$-Gain test. On a limited scale, the result of the gain of creative thinking ability was 0.784 (high) with effective criteria and the gain of environmental care was 0.566 (moderate) with quite effective criteria. Whereas in the wide-scale test, the result of creative thinking ability gain was 0.66 (moderate) with quite effective criteria and the gain of environmental care was 0.562 (moderate) with quite effective criteria. Based on the analysis of the $\mathrm{N}$-gain test it can be concluded that the thematic module of the impact of pollution on life could improve the ability to think creatively and students' perceptions of the importance of caring for the environment.
\end{abstract}

Keywords: Groundwater quality, thematic modules, creative thinking, environmental care.

\section{INTRODUCTION}

Ground water is the best source of water to meet human needs because it is cleaner, clearer and free of chemicals. However, the use of groundwater is known to have been reduced, replaced with the water from a local company, namely PDAM. Water from PDAM comes from river water that is treated with certain processes such as purification and eradication of bacteria by mixing chemicals such as chlorine and alum. In addition to higher costs, chlorine and alum content in PDAM water if used at inappropriate and continuous doses will be harmful to kidney and liver health (Ching, 2015).

Water quality testing is required to determine the quality of the water itself. This test has been carried out by researchers on a variety of different environmental conditions and by using various parameters. Water has physical, chemical and biological properties. According to Naslilmuna (2018), physical characteristics that affect water quality are determined by 
color, temperature, turbidity, and the chemical characteristics of water includes $\mathrm{pH}$, alkalinity, and hardness.

Curriculum 2013 (K-13) is a curriculum based on character and competence. Curriculum 2013 not only emphasizes the mastery of student competencies, but also the formation of characters. In accordance with the core competencies (KI) determined by the Ministry of Education and Culture, KI 1 and KI 2 relate to the purpose of building students' character while KI 3 and KI 4 relate to mastering students' competence (Mulyasa, 2013).

Attitude greatly influences the assessment of students in Curriculum 2013. It is considered as the most important aspect which should the students have, because it will affect the character of students to face life now and in the future. One of the attitudes that will build the character and behavior patterns of students towards nature or the environment is an attitude of concern for the environment (Majid, 2014). Attitude is a foundation in the human character building. The character will form a habit pattern that ultimately affects the aspect of thinking ability, namely creativity (the ability to think creatively).

Creative thinking is the ability to find many possible solutions to a problem, which emphasizes the quantity, accuracy, and diversity of answers. Creative thinking aslo considered as the ability to develop bright ideas according to the task and be able to redefine the problem effectively and think deeply (Sani, 2014). The ability to think creatively according to Davis (2012) is shown in Table 1.

Table 1 . The Creative Thinking Ability

\begin{tabular}{|c|c|c|}
\hline No & Aspect & Indicator \\
\hline 1 & Fluency & Come up with lots of ideas, answers, suggestions for solving problems \\
\hline 2 & Flexibility & Can see problems from a variety of different points of view \\
\hline & & Can apply concepts, properties, or rules in problem solving examples. \\
\hline 3 & Originality & $\begin{array}{l}\text { Triggering problems, ideas or things which other people do not think } \\
\text { about }\end{array}$ \\
\hline 4 & Elaboration & $\begin{array}{l}\text { Developing or enriching other people's ideas } \\
\text { Make a detailed and different report }\end{array}$ \\
\hline
\end{tabular}

The attitude of caring for the environment is divided into 4 indicators namely hard work to protect nature, respect for hygiene health, wise in using natural resources, and responsibile to the environment. The goals of this research were aiming to (1) Describe ground water quality in terms of several parameters, namely temperature, $\mathrm{pH}$, salinity, electrical conductivity, the amount of dissolved solids, turbidity and dissolved oxygen content; (2) Describe the improvement of the ability to think creatively using the thematic modules on the material about impacts of pollution on life on seventh grade junior high school students; and (3) Describe the increase in students' perceptions of the importance of caring for the environment using the thematic modules on the material about impacts of pollution on life.

\section{RESEARCH METHODS}

The research was conducted using a Research and Development research model for ADDIE development (Analysis, Design, Develop, Implementation, and Evaluation). The analysis of ground water quality was carried out at four different locations: 1) the wells near the Temporary Disposal Site (TDS) where located on WR Supratman street, Pematang Gubernur, Muara Bangka Hulu District, Bengkulu City; 2) the wells around flood-prone areas where located on Jalan Beringin, Tanjung Agung, Sungai Serut District, Bengkulu City; 3) the wells around clean areas where located in the Rules of Mumpo Village, Pematang Tiga District, Bengkulu Tengah Regency; 4) the well around the swamp where located on M. Ali 
Amin street, Kel. Pematangatang Muara Bangka Hulu District, Bengkulu City. The study was conducted by measuring seven parameters, namely temperature, $\mathrm{pH}$, salinity, dissolved oxygen levels, TDS, Electrical Leastility, and turbidity. This research was conducted from November 4 to December 19, 2019. Direct measurements at the location were carried out on December 5, 2019. The measurement of temperature and $\mathrm{pH}$ parameters was carried out directly at the location, while the other five parameters were carried out at the Basic Science Laboratory of Bengkulu University. The distance of each well sampled to the location of the safety tank is ideal $\geq 10 \mathrm{~m}$.

The data obtained were then analyzed by descriptive analysis method by describing the facts which were then followed by analysis. The references used are based on the Republic of Indonesia Ministerial Regulation No.32 of 2017 which is summarized in Table 2.

Table 2. Quality Standards of Clean Water

\begin{tabular}{clcc}
\hline No & \multicolumn{1}{c}{ Parameter } & Unit & Quality Standard \\
\hline 1 & Salinity & $\mathrm{ppm}$ & $<900$ \\
2 & Temperature & ${ }^{\circ} \mathrm{C}$ & $27^{\circ} \pm 3^{\circ}$ \\
3 & Turbidity & $\mathrm{NTU}$ & $\leq 5$ \\
4 & DHL & $\mathrm{mg} / \mathrm{L}$ & 1.000 \\
5 & $\mathrm{pH}$ & $\mathrm{mg} / \mathrm{L}$ & $6-8,5$ \\
6 & Dissolved Oksigen & $\mathrm{ppm}$ & $\geq 5$ \\
7 & TDS & $\mathrm{mg} / \mathrm{L}$ & $<500$ \\
\hline
\end{tabular}

Based on the results of surveys and interviews with students at SMPN 18 Bengkulu Tengah, all of the students still use well water as a fulfillment of clean water needs in their daily lives. But the students have not yet realized that these needs must be appreciated and maintained by increasing awareness of the environment. Observation results at SMPN 18 Bengkulu Tengah showed that students still had a low perception of the importance of caring for the environment. This could be seen from the large amount of garbage scattered around the school. Garbage and scattered waste would pollute the environment including the ground water which contained in the environment (Septianingsih, 2018).

The 2013 syllabus for class VII semester 2 of KD 2.3, 2.4 and 3.9 discussed about the effects of pollution for life and one of them is water pollution. This material would be very suitable for increasing students' perception of the importance of caring for the environment. In addition students were also expected to have high-level thinking skills, one of which is the ability to think creatively. The ability to think creatively was measured based on four aspects namely fluency, flexibility, originality, and elaboration.

Material impact of pollution on life was conveyed to students through thematic modules that were packaged based on the results of research on ground water quality using 7 physical and chemical parameters in 4 well water locations that have different environmental conditions. The module was also equipped with test questions in the form of essay questions to improve the ability to think creatively and also a questionnaire that is used to measure students' perceptions of the importance of caring for the environment. Before the modules and instruments were implemented, they were validated beforehand by material experts and media experts. The module was implemented on January 18-February 12, 2020. The limited scale research subjects were 10 students of class VIII while the broad scale were 21 students of class VII at SMPN 18 Bengkulu Tengah. Test questions and questionnaires were given before and after treatment using a thematic module subject to the impact of pollution on life.

The pretest and posttest results of students in creative thinking abilities and students' concern for the environment were analyzed using the N-Gain test with the formula: 


$$
N_{\text {gain }}=\frac{\text { Skor Post }- \text { Skor Pre }}{\text { Skor Max }- \text { Skor Pre }}
$$

\section{RESULTS AND DISCUSSION}

Based on the results of measurements using these seven parameters, it can be concluded that the water with the best quality is water that is located in a clean environment, away from landfills and waste. This water is well water which is located in Rules Mumpo Village, Pematang Tiga District, Bengkulu Tengah Regency. The measurement results using the seven parameters show that clean water has a quality that meets the quality standard in accordance with the Republic of Indonesia Minister of Health Regulation 2017 due to the quality standard for the seven parameters.

Swamp water is well water located on M. Ali Amin street, Pematang Gubernur, Muara Bangka Hulu District. Swamp water has a clean and garbage-free environment, but is $\pm 50 \mathrm{~m}$ away from the swamp. The measurement results show that the swamp water meets 4 standard parameters of clean water namely $\mathrm{pH}$, Salinity, TDS, and electrical conductivity. This water can still be used for washing clothes and dishes. This water will leave marks on its container. It can be seen from the brownish color seen in the water user's bathroom. This water also has a smell that is similar to the smell of mud but not overpowering.

Flood water is water that is located around areas prone to flooding, and is always affected when a flood occurs. This well is located on Beringin street, Tanjung Agung, Sungai Serut District, Bengkulu City. Flood water meets 4 standard parameters of clean water standards, namely parameters of temperature, $\mathrm{pH}$, TDS, and electrical conductivity. This water is the most turbid water when compared to the other water. So that before they use this water, it must be deposited first. This water will produce a thick enough sediment in the container container. This well water is only used for washing and bathing needs. But for residents who are not accustomed to using water and have sensitive skin, they will feel itchy based on the information of residents who are the owner of the well.

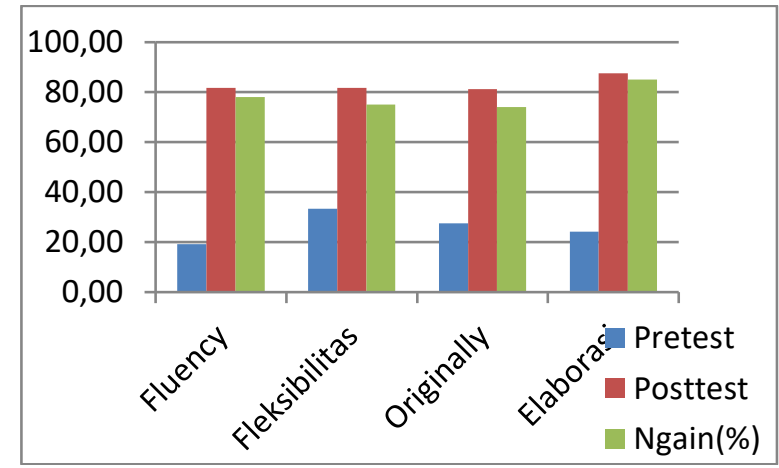

Figure 1. Pretest, Posttest, Ngain Creative Thinking Limited Class

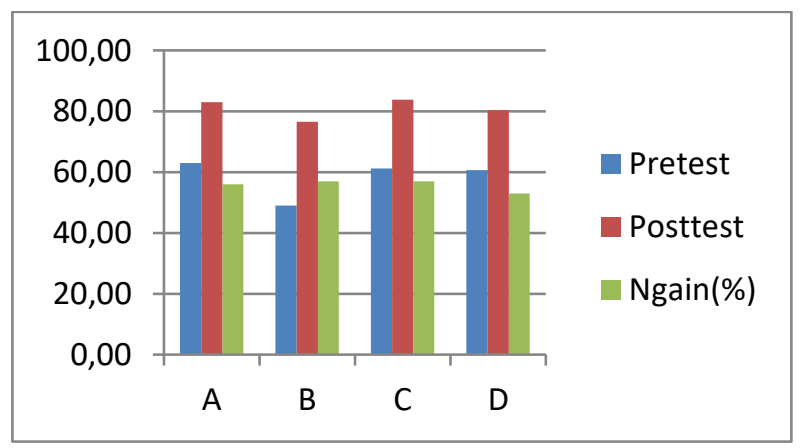

Figure 2. Pretest, Posttest, Ngain Care for the Environment Limited Class 
TPS water is well water located at a temporary disposal site. This water is located on WR Supratman Street, Pematang Gubernur, Muara Bangka Hulu District, Bengkulu City. The well is surrounded by scattered rubbish, ranging from plastic waste and rotten vegetables. The most common waste is plastic, but this water is still actively used. This water only meets 3 parameters namely $\mathrm{pH}$, temperature, and salinity. This water is not suitable for use as sanitary hygiene needs. Because this water seems to contain a lot of brownish moss when viewed directly at the well. This water is only suitable for watering plants.

Based on measurements taken of 4 well water with 4 different environmental conditions, the environment greatly affects the condition of ground water that is at their location. Land has a different structure, some have a high absorption and some are low. Because the nature of the soil is to absorb liquid, the water contained therein will contain materials found on the surface of the soil.

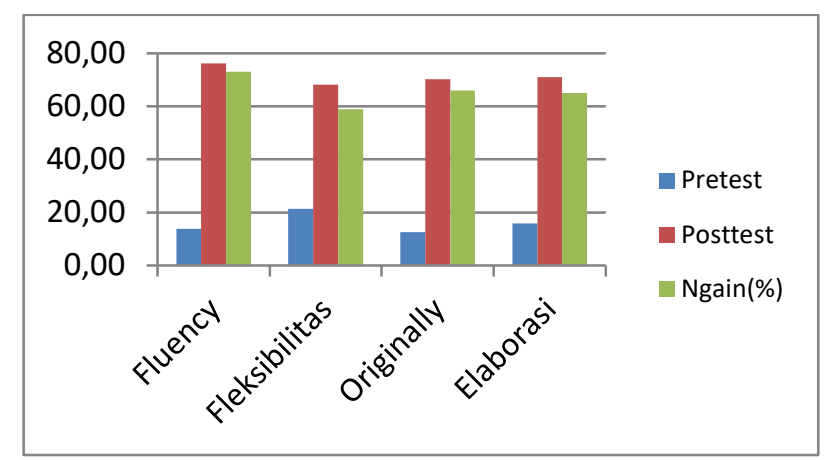

Figure 3. Pretest, Posttest, Ngain Creative Thinking in a Wide Class

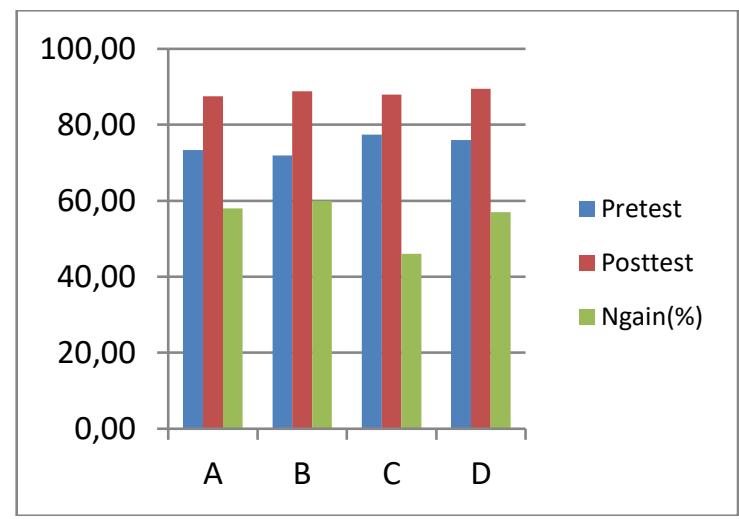

Figure 4. Pretest, Posttest, Ngain Care for the Environment In a Wide Class

Groundwater quality in this study in terms of physical and chemical parameters produced a significant difference according to the environmental conditions of the well water location. The best quality of well water is water that is located in a clean environment, free from garbage and waste. This well is located in the Mumpo Village of Bengkulu Tengah Regency. So that this well can be categorized as water source that has a very good quality. Whereas water that has poor quality is water located in flood prone areas and around polling stations. This location is the most frequently affected by flooding and there are various types of rubbish around it. So, it can be concluded that the environment greatly influences the quality of ground water in terms of physical and chemical parameters. A clean environment will contain clean and healthy groundwater, while a dirty environment will produce poor ground water and contain substances that are harmful to human health. The results of measurements 
of groundwater quality are packaged into thematic modules to see an increase in the ability to think creatively and students' perceptions of the importance of caring for the environment. The results of the pretest, posttest, and N-Gain test results were presented in the Figures 1 to 4.

\section{CONCLUSION}

Measurement of groundwater quality at four different locations using seven parameters namely temperature, $\mathrm{pH}$, salinity, dissolved oxygen content, dissolved solid content, TDS, and turbidity produced different water qualities. Well water which is located in a clean environment meets the quality standard of clean water in seven parameters, well water around the swamp and areas that are often flooded meets the clean water quality standard in 4 parameters, while well water where is around the TPS meets the clean water standard only 3 parameters. So that environmental conditions greatly affect the quality of ground water contained therein, a clean and uncontaminated environment will produce clean and healthy groundwater while a dirty and polluted environment will be a source of ground water with poor quality.

The thematic module about the impact of pollution on life with a limited scale has an effective influence in increasing the ability to think creatively, this is proved by the acquisition of an average $\mathrm{N}$-gain score of 0.784 with high criteria. While on the broad scale thematic modules about the impact of pollution on life has an effect that is quite effective in improving students' creative thinking abilities with the acquisition of an average $\mathrm{N}$-gain score of 0.566 which mean moderate criteria. The thematic module of the impact of pollution on life on both a limited and broad scale has an effect that is effective enough to increase students' perceptions of the importance of caring for the environment, this is proved by the results of obtaining an average $\mathrm{N}$-gain score on a limited scale of 0.66 with criteria average and $\mathrm{N}$-gain average score on a broad scale of 0.562 with moderate criteria.

\section{REFERENCES}

Amelia, S.E.R., dan Suranto. (2016). Pengembangan Modul Pembelajaran Standar Kompetensi Mengaplikasikan Keterampilan Dasar Komunikasi Kelas X SMK Muhammadiyah 1 Wates. Jurnal Pendidikan Administrasi Perkantoran, 5(2), 106-116.

Aryani, F.D.N. (2017). Kualitas Air Tanah Di Sekitar Lokasi Tempat Pembuangan Akhir Untuk Pemenuhan Kebutuhan Air Bersih (Studi Kasus: TPA Banyuroto Dan TPA Piyungan), Geo Educasia, 2(8), 1047-1057.

Astuti, P. (2017). Peningkatan Motivasi Dan Kemampuan Berpikir Kreatif Siswa Pada Materi Pencemaran Lingkungan Melalui Media Fotonovela, Refleksi Edukatika: Jurnal Ilmiah Kependidikan, 8(1).

Ching, Y.C., Lee, Y.H., Toriman, M.E., \& Abdullah, M., Baharudin. (2015). Effect of the big flood events on the water quality of the Muar River, Malaysia. Sustainable Water Resources Management, 1(2), 97-110.

Davis, G.A. (2012). Anak Berbakat \& Pendidikan Keberbakatan. (terjemahan Ati Cahayani). Scottsdale: Great Potensial Press.

Irawati, H. (2015). Pengembangan Modul Pembelajaran IPA dengan Tema Pencemaran Lingkungan untuk meningkatkan hasil belajar siswa SMP kelas VII. Jurnal Bioedukatika, 3(1), 16-20.

Majid, Abdul. (2014). Pembelajaran Tematik Terpadu. Bandung: PT Remaja Rosdakarya Offset.

Mulyasa, Endang. (2013). Riset Terapan Bidang Pendidikan dan Teknik. Yogyakarta: UNY Press. 
Naslilmuna, M., Muryani, C., Santoso, S. (2018). Analisis Kualitas Air Tanah dan Pola Konsumsi Masyarakat Sekitar Industri Kertas PT Jaya kertas Kecamatan Kertososno Kabupaten Nganjuk, GeoEco, 4(1), 51-58.

Sani, R.A. (2014). Pembelajaran Saintifik untuk Implementasi Kurikulum 2013. Jakarta: PT.Bumi Aksara.

Septianingsih, D. A., Firdaus, M. L., \& Farid, M. (2018). Pengukuran kualitas dan muka air tanah di sekitar PT. Bio Nusantara Teknologi untuk mendukung proses pembelajaran fisika. Pendipa Journal Of Science Education, 2(1), 76-81.

Tim Pusat Pengembangan Profesi Pendidik. (2014). Implemantasi Kurikulum 2013 SMP/MTs. Jakarta: Badan Pengembangan Sumber Daya Manusia Pendidikan dan Kebudayaan dan Penjaminan Mutu Pendidikan. 